\title{
Spectral Studies of Some Transition Metal Ion complexes with 4- [(E)-(Ferrocene-1-Methylidene) Amino] Pyridin-2-ol
}

\author{
Manohar V Lokhande ${ }^{1}$ and Gulam Farooq $\mathrm{M}^{2}$ \\ ${ }^{I}$ Department of Chemistry, Sathaye College, Mumbai-400057(Maharashtra-India) \\ ${ }^{2}$ Department of Chemistry, Sir Sayyed College, Aurangabad-431001(Maharashtra-India) \\ ${ }^{2}$ Department of Chemistry, Shri Jagdish Prasad Jhabarmal Tibrewala University, Vidya Nagari, Jhunjhunu - \\ Churu Road, Chudela, Dist. Jhunjhunu -333001,(Rajasthan-India).
}

\begin{abstract}
Several new complexes of some transition metal ions with organometallic compounds were derived from ferrocencecarboxylaldehyde and 4-amino-2-hydroxy pyridine. These organometallic complexes were investigated by using some analytical techniques like infrared, mass spectra, electronic spectra, electron spin resonance, thermal analysis, magnetic moment, conductivity and antimicrobial activity. From the obtained elemental analysis data, organometallic compounds complexes shows 1:2 [M: L] ratio and general formula of the complex is $\left[\mathrm{ML}_{2} \cdot 2 \mathrm{H}_{2} \mathrm{O}\right]$. These complexes revealed a non-electrolytic nature. The magnetic moment values of the complexes exhibited the paramagnetic as well as diamagnetic in nature. The coordination behavior of the metal ions towards to the investigated organometallic compounds takes place through $>\mathrm{C}=\mathrm{N}$ - and $-\mathrm{OH}$ groups. The electronic spectral data shows that all the complexes are covalent in nature, octahedral structure with co-ordination number six. Organometallic compound complexes were loses two water molecules subjected to simultaneous thermo gravimetric analysis, to study their decomposition mechanism and thermal stability. Mass spectra of the organometallic compound and their complexes are matched with theoretical values of the masses. The prepared organometallic compounds and their metal complexes were screened for their antibacterial activity against some bacterial species, Escherichia coli, Pseudomonas aeruginosa and Staphylococcus Pyogones. The Antimicrobial activity data show the metal complexes to be more active than the parent organometallic compounds.
\end{abstract}

Key words: Ferrocencecarboxylaldehyde, 4-Amino-2-Hydroxy Pyridine, Infrared, Mass Spectra, Electronic Spectra, ESR, Thermal Analysis, Conductivity and Antimicrobial Activity.

\section{Introduction}

The coordination chemistry of organometallic compounds has a significant role as ligands from last two decade after its discovery [1,2]. Organometallic compounds and its metal ion complexes are important owing to their biochemical synthesis [3], electrochemical analysis [4], analytical methods [5], antifungal, antimicrobial activities [6-9] and used as a catalysts [10-11]. Organometallic compound containing nitrogen, oxygen and sulphur atom donors have structurally identical with natural biological systems. In the biological systems due to presence of azomethane $(>\mathrm{C}=\mathrm{N}-)$ groups [12], Presence of nitrogen $\left(-\mathrm{NH}_{2)}\right.$ and oxygen from hydroxyl $(-\mathrm{OH})$ or carboxylic group (-COOH) donor atoms properties of the complexes to a great extent as effective and stereo specific catalysts for oxidation, reduction and hydrolysis [13]. Different types of organometallic compounds with metal ion complexes have been extensively studied and exhibit wide applications, especially in biological systems [14]. The study of mono, di, tridentate metal ion metal complexes shows spectral properties, therefore these kind of complexes still continue to play a very important role in our understanding of various aspects of coordination chemistry of metals. They play significant role in numerous biological systems [15-16] due to their coordinating ability with various transition metals to form organometallic compounds. In this paper we are presenting the preparation method, spectral studies and antimicrobial studies of schiff bases organometallic compounds and their metal ion complexes.

\section{Experimental Methods:}

All the chemicals and reagents were used for this research work in analytical grade, used without any further purification.

2.1 Preparation of organometallic compound: Ferrocencecarboxylaldehyde (0.306g) and 4-Amino-2Hydroxy Pyridine $(0.110 \mathrm{~g})$ were separately dissolved in $100 \mathrm{~cm}^{3}$ alcohol. The equal volume of the both the compounds were mixed in round bottom flask, few drops of acetic acid were added. Then this reaction mixture were reflux for near about five hours using water condenser, after complete refluxation, solution were cool at room temperature over night for 48 hours solid separates. This solid compound keeps for drying at $60{ }^{\circ} \mathrm{C}$ in oven. The yield of organometallic compound is $74 \%$. 
2.2 Preparation of organometallic complexes: The organometallic complexes were prepared by mixing equi molar concentration $(0.01 \mathrm{M})$ of ethanolic solutions of the 4-[(E)-(Ferrocene-1-Methylidene) Amino] Pyridin-2ol with the $(0.01 \mathrm{M})$ aqueous solution of $\mathrm{Mn}$-acetate, Co-acetate, Ni-acetate, $\mathrm{Cu}$-acetate, $\mathrm{Zn}$-acetate, $\mathrm{PdCl}_{2} \&$ $\mathrm{PtCl}_{2}$ salts. These solutions were mixed and refluxed for three hours using 304 drops of alcoholic ammonia solution. After three hours, the complexes were cooled at room temperature, filtered, washed with ether and dried at $60^{\circ} \mathrm{C}$ in oven. The yields of product were obtained in between $52-65 \%$.

\subsection{Reaction:}

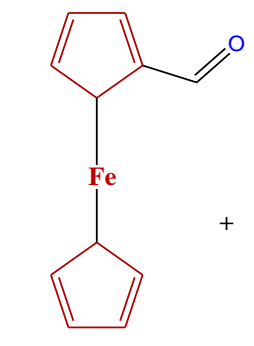

ferrocene carboxyldehyde

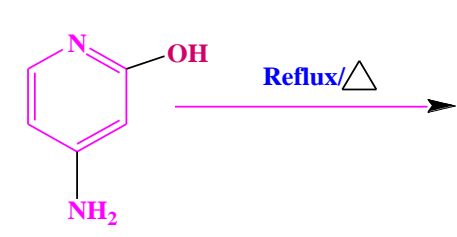

4-aminopyridin-2-ol

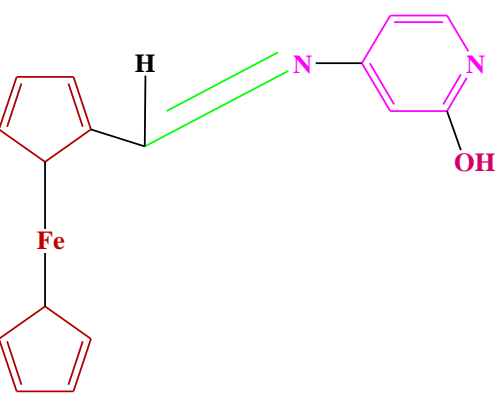

4-[(E)-(Ferrocene-1-Methylidene) Amino] Pyridin-2-ol

\section{Result and Discussion:}

The analytical and physical properties of organometallic compound and complexes are given in table: 1. The organometallic compound and their complexes were coloured, stable at room temperature for long time. The organometallic compound is soluble in alcohol but complexes were insoluble in organic solvents like toluene, methanol, ethanol, acetonitrile \& chloroform. They were soluble in dimethyl sulfoxide and dimethyl formamide. They are decomposed in the range $210-240^{\circ} \mathrm{C}$. The melting point and decomposition point were reported in open capillary but found uncorrected. The molar conductivity values of the complexes are observed in dimethyl sulfoxide in $10^{-3}$ molar solution. It is non-electrolytic in nature [17-18]. The metals contents were estimated by volumetric titration using different indicators with $(0.01 \mathrm{M})$ ethylene diamine tetra acetate solution expect palladium and platinum metal they are estimated by AAS method. Iron content was estimated by gravimetrically. The metal-ligand ratio is 1:2.

3.1 Infrared spectra: The infrared spectra of organometallic compound and complexes were compared with substituted moieties. The ligand shows prominent bands at $3415 \mathrm{~cm}^{-1}$ due to $v-\mathrm{OH}$ (hydroxyl ion) absorption. The bands observed at $1680 \mathrm{~cm}^{-1}$ due to azomethane $(>\mathrm{C}=\mathrm{N}-)$ group present in the organometallic compound. In the complexes band due to the -OH9hydroxyl Group) is not found because there is coordination with metal ions. The band are shifted to the lower frequency in azomethane $(>\mathrm{C}=\mathrm{N}-)$ group due bonding with metal ions in the range at $1630-1605 \mathrm{~cm}^{-1}$. The two new bands were observed in range between at 3450-3420 and 3520-3490 $\mathrm{cm}^{-1}$ for two coordinated water molecules. The bands observed far infrared region at $545-530 \mathrm{~cm}^{-1}$ due to $(\mathrm{M} \rightarrow \mathrm{N})$ linkage and $485-465 \mathrm{~cm}^{-1}$ for $(\mathrm{M} \rightarrow \mathrm{O})$. The central metal ions have six co-ordinate numbers and ligand behaves as a bidentate [19-26]. IR bands of the organometallic compound and complexes are reported in table: 2 .

3.2 Electronic spectra: The spectral parameters and assignment are given in Table: 3.The electronic d-d transition bands normally show weak perturbation due to complexation an increase in the intensity, shift to the red region and also splitting of some bands are observed on complex formation. The position, shapes of $\mathrm{Cu}^{+2}$ and $\mathrm{Ni}^{+2}$ are observed in solution phase using ethanol and dimethyl sulfoxide. The $\mathrm{Cu}^{+2}$ complexes shows two peaks and $\mathrm{Co}^{+2}$ complexes shows three intense peak, which have lower energies as compared to those of aqua complex. The magnitude of the bathochromic shift of the bands in each case meager Nephelauxetic effect $(\beta)$ [27], the bonding parameter (b1/2) [28] and Sinha's parameter ( $\delta \%$ ) [29] have been calculated. The bonding parameter reflects the participation of $3 d$ orbital [30]. The $b^{1 / 2}$ value obtained for the present complexes indicates a decreasing order of $3 \mathrm{~d}$ - orbital participation in the $\mathrm{Cu}^{+2}$ and $\mathrm{Ni}^{+2}$ complexes. The average value of Sinha's parameter $(\delta \%)$ obtained in each case is positive and smaller, indicating the presence of weak covalent bonding in the complexes [31].

3.3 Magnetic Moment: The corrected magnetic moment ( $\mu$ eff) in Bohr magneton units of the organometallic complexes are given in Table: 1. The magnetic moments of the complexes measured at room temperature except 
that of zinc (II) complex are diamagnetic, while other complexes are paramagnetic in nature. This indicates slight participation of the $3 d$ electron in bond formation [32].

3.4 Thermal analysis: Thermogravimatric and differential thermal analysis results of $[\mathrm{Pd}$ $\left.\left(\mathrm{C}_{16} \mathrm{H}_{13} \mathrm{~N}_{2} \mathrm{OFe}\right)_{2} .2 \mathrm{H}_{2} \mathrm{O}\right]$ and $\left[\mathrm{Pt}\left(\mathrm{C}_{16} \mathrm{H}_{13} \mathrm{~N}_{2} \mathrm{OFe}\right)_{2} .2 \mathrm{H}_{2} \mathrm{O}\right]$ are reported as below . The complexes lose weight due to exothermic and endothermic process. These complexes are thermally stable at room temperature and decompose in different steps.

3.4.1 [Pd $\left(\mathrm{C}_{16} \mathrm{H}_{13} \mathrm{~N}_{2} \mathrm{OFe}\right)_{2} .2 \mathrm{H}_{2} \mathrm{O}$ ] Complex: Thermal analysis study of $\mathrm{Pd}^{+2}$ complex shows loss in weight in the temperature range $80-130^{\circ} \mathrm{C}$, which is corresponds to loss of one water molecule and some part of complex. The experimental percentage loss, which is calculated from Thermogravimatric analysis curve, is $7.78 \%$. This value comparable with theoretical percentage loss. The differential thermal analysis peak at this range is endothermic [33]. In the temperature range $130^{\circ} \mathrm{C}-440^{\circ} \mathrm{C}$, the some part of complex is lost. The major part of complex agent is lost in the temperature range of $440-600^{\circ} \mathrm{C}$. The experimental percentage loss is $33.72 \%$, which is obtained from Thermogravimatric analysis curve. The experimental percentage loss value is comparable with theoretical percentage loss value i.e. $36.17 \%$. The differential thermal analysis peak is exothermic [34]. The probable leaving part of complex in this temperature range is $\mathrm{C}_{10} \mathrm{H}_{10}$. The temperature range $600-810^{\circ} \mathrm{C}$ leading to the formation of Palladium oxide. The decomposition of complex represented as below.

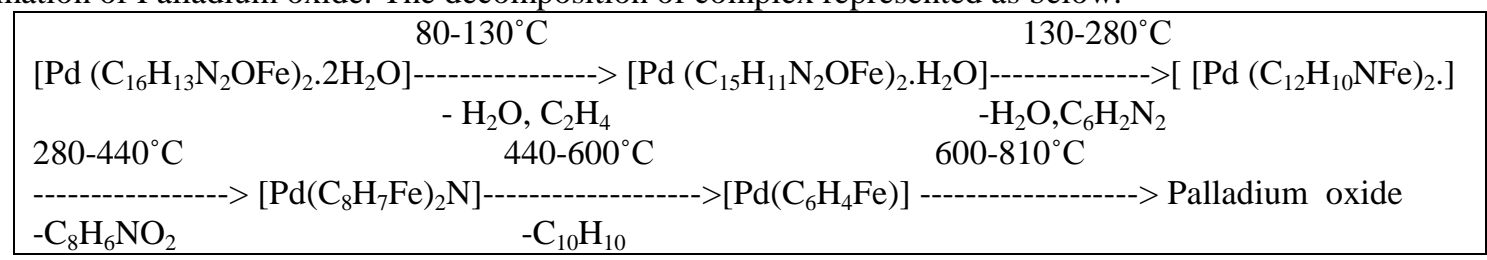

3.4.2 [Pt $\left(\mathrm{C}_{16} \mathrm{H}_{13} \mathrm{~N}_{2} \mathrm{OFe}\right)_{2} .2 \mathrm{H}_{2} \mathrm{O}$ Complex: Thermal analysis study of $\mathrm{Pt}^{+2}$ complex shows loss in weight in the temperature range $90-140^{\circ} \mathrm{C}$, which is corresponds to loss of water molecule and some part of the complex. The experimental percentage loss, which is calculated from Thermogravimatric analysis curve, is $7.72 \%$. This value comparable with theoretical percentage loss. The differential thermal analysis peak at this range is endothermic. In the temperature range $140-450^{\circ} \mathrm{C}$, the some part of complex is lost. The major part of chelating agent is lost in the temperature range of $450-600^{\circ} \mathrm{C}$. The experimental percentage loss is $33.45 \%$, which is obtained from Thermogravimatric analysis curve. The experimental percentage loss value is comparable with theoretical percentage loss value i.e. $36.18 \%$. The differential thermal analysis peak is exothermic. The probable leaving part of complex in this temperature range is $\mathrm{C}_{12} \mathrm{H}_{8}$. The temperature range $600-810^{\circ} \mathrm{C}$ leading to the formation of Platinum oxide. The decomposition of complex represented as below.

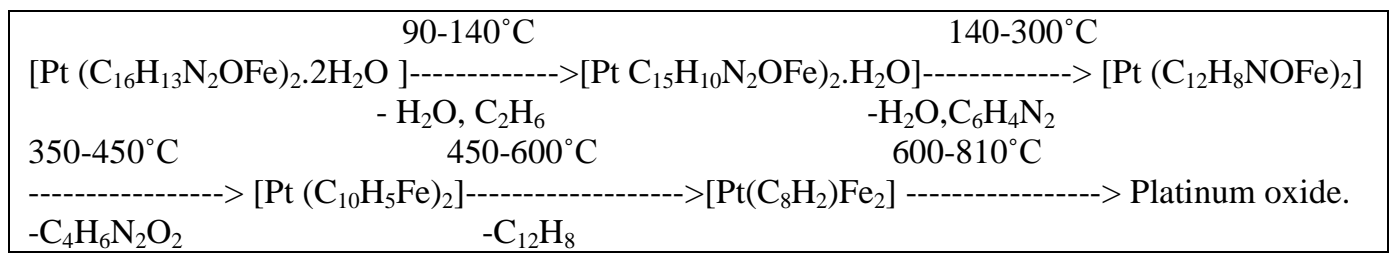

3.5 Mass spectra: The ESI mass spectra of the organometallic compound, their metal complexes recorded and are listed in table: 4 and fig $3 \& 4$. The mass spectra organometallic compound shows a molecular ion peak at $\mathrm{m} / \mathrm{z}=322.2$. The $\mathrm{Mn}$ (II) complex shows a molecular ion peak at $\mathrm{m} / \mathrm{z}=700.87$ and $\mathrm{Zn}$ (II) complex shows a peak at $\mathrm{m} / \mathrm{z}=712.7$ which corresponds to molecular weight of the respective compounds. While Co (II) complex shows $\mathrm{m} / \mathrm{z}=707.12$ and $\mathrm{Cu}$ (II) complex at $\mathrm{m} / \mathrm{z}=711.13$ which corresponds to [M+1].The $\mathrm{Ni}$ (II) complex shows $\mathrm{m} / \mathrm{z}=704.2$ which corresponds to [M+2] peak respectively. The $\mathrm{Pd}$ (II) and $\mathrm{Pt}$ (II) complexes show the $\mathrm{m} / \mathrm{z}$ peaks at $753.45 \& 842.12$ respectively. These peaks support to the structure of the complexes and confirm the stochiometric of organometallic complexes were $\left[\mathrm{ML}_{2} .2 \mathrm{H}_{2} \mathrm{O}\right]$ type. The different molecular ion peaks appeared in the mass spectra of complexes (abundance range 2-100\%) are attributed to the fragmentation of the metal complex molecule obtained from the rupture of different bonds inside the molecule by successive degradation leading to many more important peaks due to formation of various radicals[35]. The spectra of complexes show molecular ion peaks in good agreement with the structure suggested by elemental analysis, spectral and magnetic studies. The spectra of the organometallic compounds and its complex shows characteristic molecular ion peak at their expected $\mathrm{m} / \mathrm{z}$ values confirming their monomeric form [36]. 
3.6 Electron spin resonance: The Electron spin resonance spectra of organometallic complexes provide information on the basis of hyperfine and superhyperfine structures. Electron spin resonance spectra of the [Cu $\left(\mathrm{C}_{16} \mathrm{H}_{13} \mathrm{~N}_{2} \mathrm{OFe}\right)_{2} .2 \mathrm{H}_{2} \mathrm{O}$ ] complex have been recorded on $\mathrm{X}$-band fig 5 and their $\mathrm{g}_{\mathrm{II}}, \mathrm{g}_{\mathrm{I}}, \mathrm{g}_{\mathrm{av}}, \Delta \mathrm{g}$ and $\mathrm{G}$ values have been calculated. The ESR parameters of $\left[\mathrm{Cu}\left(\mathrm{C}_{16} \mathrm{H}_{13} \mathrm{~N}_{2} \mathrm{OFe}\right)_{2} .2 \mathrm{H}_{2} \mathrm{O}\right]$ complex $\mathrm{g}_{\mathrm{II}}, \mathrm{g}_{\mathrm{I}}, \mathrm{g}_{\mathrm{av}}$ and $\Delta \mathrm{g}$ have 2.01 , 2.11, 2.05 and 0.08 respectively. The X-band EPR spectrum of $\left[\mathrm{Cu}\left(\mathrm{C}_{16} \mathrm{H}_{13} \mathrm{~N}_{2} \mathrm{OFe}\right)_{2} .2 \mathrm{H}_{2} \mathrm{O}\right]$ complex shows a single line at $\mathrm{g} \approx 2.01$, which is attributed to a single $\mathrm{s}=1 / 2$ species; this provides information about the extent of the delocalization of unpaired electron [37-39]. The $\mathrm{g}_{\mathrm{II}}<\mathrm{g}_{\mathrm{I}}$ value shows the covalent nature of M:Lbond. The value of ESR parameters of [ $\left.\mathrm{Ni}\left(\mathrm{C}_{16} \mathrm{H}_{13} \mathrm{~N}_{2} \mathrm{OFe}\right)_{2} .2 \mathrm{H}_{2} \mathrm{O}\right]$ complex, $\mathrm{g}_{\mathrm{II}}, \mathrm{g}_{\mathrm{I}}, \mathrm{g}_{\mathrm{av}}, \Delta \mathrm{g}$ and $\mathrm{G}$ have 2.214, 2.322, 2.272, 0.062 and 1.64 respectively. The covalent nature of the M:L bond in the complex is further supported by the $\mathrm{G}$ value which is $<4.0$. The value $\mathrm{g}_{\mathrm{II}}>\mathrm{g}_{\mathrm{I}}$ is well consistent with aprimarily $\mathrm{dx}^{2}-\mathrm{y}^{2}$ ground state. The $\mathrm{G}$ value of 1.64 indicates considerable exchange interaction in the complex. According to Hathway, if the value of $G$ is greater than four, the exchange interaction is negligible; whereas when the value of $G$ is less than 4 to considerable exchange interaction is indicated in the complex. The parameter $\mathrm{g}_{\mathrm{av}}$ were obtained by equation $\left[g_{a v}=\left(1 / 3 g_{I I+} g_{I}\right)\right]$. The $g_{I I}$ value $(<2.3)$ indicates covalent character of the M:L bond [40-41].

3.7 Antimicrobial activity: Organometallic compound and its complexes have been screened in-vitro against the some bacteria like Escherichia coli, Pseudomonas aeruginosa and Staphylococcus Pyogones species by well diffusion method using agar as nutrient medium. Here streptomycin has been used as a standard. The microbial activity of the schiff base organometallic compound and its complexes are listed in table: 5. All the complexes shows higher antibacterial activity against Escherichia coli and Pseudomonas aeruginosa. On the other hand for Staphylococcus Pyogones bacteria shows more biological activity towards schiff base organometallic compound.

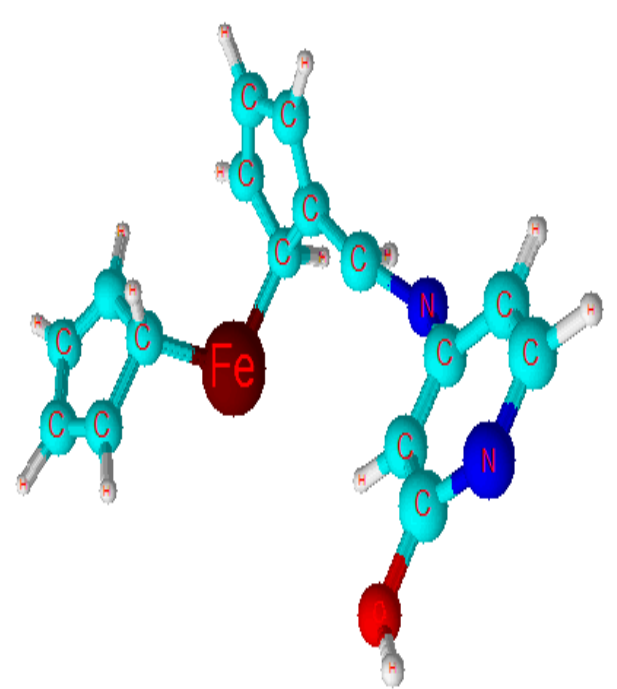

Fig: 1 . 3D View of organometallic comp.

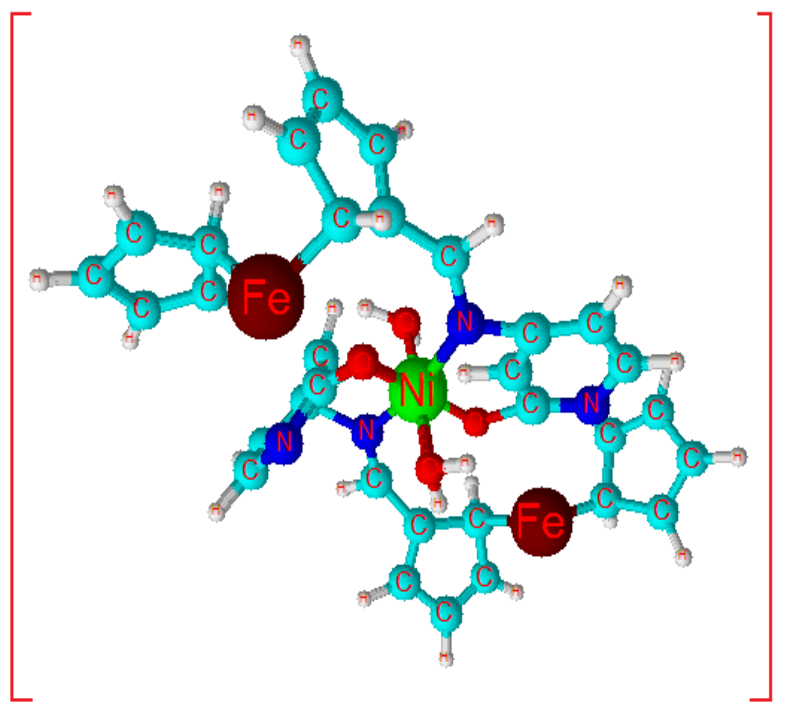

Fig:2. Structure of $\left[\mathrm{Ni}\left(\mathrm{C}_{16} \mathrm{H}_{13} \mathrm{~N}_{2} \mathrm{OFe}\right)_{2} \cdot 2 \mathrm{H}_{2} \mathrm{O}\right]$ complex

\begin{tabular}{|c|c|c|c|c|c|c|c|}
\hline Schiff base /Complexes & $\%$ yield & $\mathrm{MP} / \mathrm{DP}{ }^{\circ} \mathrm{C}$ & $\mathrm{C} \%$ & $\mathrm{~N} \%$ & $\mathrm{Fe} \%$ & M\% & BM. $\mu$ eff \\
\hline \multirow[t]{2}{*}{$\mathrm{C}_{16} \mathrm{H}_{14} \mathrm{~N}_{2} \mathrm{OFe}$} & \multirow[t]{2}{*}{74} & \multirow[t]{2}{*}{$255-258$} & 62.77 & 9.15 & 18.24 & & \\
\hline & & & $62.42 *$ & $8.95 *$ & $17.98 *$ & & \\
\hline \multirow{2}{*}[\mathrm{Mn}(\mathrm{C}_{16}\mathrm{H}_{13}\mathrm{N}_{2}\mathrm{OFe})_{2}.2\mathrm{H}_{2}\mathrm{O}]{} & \multirow[t]{2}{*}{53} & \multirow[t]{2}{*}{$237-240$} & 54.81 & 7.99 & 15.93 & 7.83 & \multirow[t]{2}{*}{5.48} \\
\hline & & & 54.34 & 7.55 & 15.59 & 7.45 & \\
\hline \multirow{2}{*}[\mathrm{Co}(\mathrm{C}_{16}\mathrm{H}_{13}\mathrm{N}_{2}\mathrm{OFe})_{2}.2\mathrm{H}_{2}\mathrm{O}]{} & \multirow[t]{2}{*}{61} & \multirow[t]{2}{*}{$235-238$} & 54.5 & 7.94 & 15.84 & 8.36 & \multirow[t]{2}{*}{4.40} \\
\hline & & & 54.11 & 7.59 & 15.74 & 8.05 & \\
\hline \multirow[t]{2}{*}[\mathrm{Ni}(\mathrm{C}_{16}\mathrm{H}_{13}\mathrm{N}_{2}\mathrm{OFe})_{2}\cdot2\mathrm{H}_{2}\mathrm{O}]{} & \multirow[t]{2}{*}{54} & \multirow[t]{2}{*}{$232-235$} & 54.52 & 7.95 & 15.84 & 8.33 & \multirow[t]{2}{*}{3.21} \\
\hline & & & 54.22 & 7.59 & 15.71 & 8.01 & \\
\hline \multirow{2}{*}[\mathrm{Cu}(\mathrm{C}_{16}\mathrm{H}_{13}\mathrm{N}_{2}\mathrm{OFe})_{2}.2\mathrm{H}_{2}\mathrm{O}]{} & \multirow[t]{2}{*}{62} & \multirow[t]{2}{*}{$227-230$} & 54.14 & 7.89 & 15.73 & 8.95 & \multirow[t]{2}{*}{1.87} \\
\hline & & & 53.85 & 7.58 & 15.42 & 8.70 & \\
\hline \multirow{2}{*}[\mathrm{Zn}(\mathrm{C}_{16}\mathrm{H}_{13}\mathrm{N}_{2}\mathrm{OFe})_{2}.2\mathrm{H}_{2}\mathrm{O}]{} & \multirow[t]{2}{*}{58} & \multirow[t]{2}{*}{$221-224$} & 54.01 & 7.87 & 15.69 & 9.19 & \multirow[t]{2}{*}{ dimag } \\
\hline & & & 53.72 & 7.59 & 15.41 & 8.92 & \\
\hline \multirow{2}{*}[\mathrm{Pd}(\mathrm{C}_{16}\mathrm{H}_{13}\mathrm{N}_{2}\mathrm{OFe})_{2}.2\mathrm{H}_{2}\mathrm{O}]{} & \multirow[t]{2}{*}{52} & \multirow[t]{2}{*}{$215-218$} & 51.06 & 7.44 & 14.84 & 14.14 & \\
\hline & & & 50.82 & 7.17 & 14.59 & 13.95 & \\
\hline \multirow[t]{2}{*}[\mathrm{Pt}(\mathrm{C}_{16}\mathrm{H}_{13}\mathrm{N}_{2}\mathrm{OFe})_{2}.2\mathrm{H}_{2}\mathrm{O}]{} & \multirow[t]{2}{*}{54} & \multirow[t]{2}{*}{$210-213$} & 45.68 & 6.66 & 13.27 & 23.19 & \\
\hline & & & 45.31 & 6.35 & 13.01 & 22.91 & \\
\hline
\end{tabular}

Table .1: Analytical, Physical Data of Schiff Base organometallic and Complexes [(*) Experimental value] 
Spectral Studies of Some Transition Metal Ion complexes with 4-[(E)-(Ferrocene-1-Methylidene)

\begin{tabular}{|l|l|l|l|l|l|}
\hline Schiff base /Complexes & vC-OH & vC=N & vM-N & vM-O & $2 \mathrm{H}_{2} \mathrm{O}$ \\
\hline $\mathrm{C}_{16} \mathrm{H}_{13} \mathrm{~N}_{2} \mathrm{OFe}$ & 3415 & 1680 & & & - \\
\hline$\left[\mathrm{Mn}\left(\mathrm{C}_{16} \mathrm{H}_{13} \mathrm{~N}_{2} \mathrm{OFe}\right)_{2} \cdot 2 \mathrm{H}_{2} \mathrm{O}\right]$ & & 1608 & 543 & 472 & 3445,3498 \\
\hline$\left[\mathrm{Co}\left(\mathrm{C}_{16} \mathrm{H}_{13} \mathrm{~N}_{2} \mathrm{OFe}\right)_{2} \cdot 2 \mathrm{H}_{2} \mathrm{O}\right]$ & & 1614 & 538 & 467 & 3422,3502 \\
\hline$\left[\mathrm{Ni}\left(\mathrm{C}_{16} \mathrm{H}_{13} \mathrm{~N}_{2} \mathrm{OFe}\right)_{2} \cdot 2 \mathrm{H}_{2} \mathrm{O}\right]$ & & 1622 & 527 & 465 & 3442,3510 \\
\hline$\left[\mathrm{Cu}\left(\mathrm{C}_{16} \mathrm{H}_{13} \mathrm{~N}_{2} \mathrm{OFe}\right)_{2} \cdot 2 \mathrm{H}_{2} \mathrm{O}\right]$ & & 1630 & 532 & 472 & 3428,3495 \\
\hline$\left[\mathrm{Zn}\left(\mathrm{C}_{16} \mathrm{H}_{13} \mathrm{~N}_{2} \mathrm{OFe}\right)_{2} \cdot 2 \mathrm{H}_{2} \mathrm{O}\right]$ & & 1623 & 538 & 478 & 3437,3518 \\
\hline$\left[\mathrm{Pd}\left(\mathrm{C}_{16} \mathrm{H}_{13} \mathrm{~N}_{2} \mathrm{OFe}\right)_{2} \cdot 2 \mathrm{H}_{2} \mathrm{O}\right]$ & & 1614 & 533 & 480 & 3430,3490 \\
\hline$\left[\mathrm{Pt}\left(\mathrm{C}_{16} \mathrm{H}_{13} \mathrm{~N}_{2} \mathrm{OFe}\right)_{2} \cdot 2 \mathrm{H}_{2} \mathrm{O}\right]$ & & 1605 & 525 & 485 & 3444,3514 \\
\hline
\end{tabular}

Table 2 : Relevant IR Spectral Data Of The Schiff Base and Its Complexes in $\mathbf{C m}^{-1}$

\begin{tabular}{|c|c|c|l|}
\hline Complexes & Absorption bands cm $\mathrm{c}^{-1}$ & Assignments & Spectral Parameter \\
\hline & 20730 & ${ }^{3} \mathrm{~A}_{2 \mathrm{~g}}(\mathrm{~F}) \rightarrow{ }^{3} \mathrm{~T}_{1 \mathrm{~g}}(\mathrm{~F})$ & $\beta=0.9695$ \\
& 14200 & ${ }^{3} \mathrm{~A}_{2 \mathrm{~g}}(\mathrm{~F}) \rightarrow{ }^{3} \mathrm{~T}_{1 \mathrm{~g}}(\mathrm{~F})$ & $\delta \%=1.58$ \\
& 11275 & ${ }^{3} \mathrm{~A}_{2 \mathrm{~g}}(\mathrm{~F}) \rightarrow{ }^{3} \mathrm{~T}_{2 \mathrm{~g}}(\mathrm{~F})$ & $\mathrm{b}^{1 / 2}=0.0873$ \\
& & & $\eta=0.0156$ \\
\hline & 25840 & ${ }^{4} \mathrm{~T}_{1 \mathrm{~g}} \rightarrow{ }^{4} \mathrm{~A}_{2 \mathrm{~g}}(\mathrm{P})$ & $\beta=0.9610$ \\
& 13345 & ${ }^{4} \mathrm{~T}_{1 \mathrm{~g}} \rightarrow{ }^{4} \mathrm{~T}_{2 \mathrm{~g}}$ & $\delta \%=2.05$ \\
& & & $\mathrm{~b}^{1 / 2}=0.099$ \\
& & & $\eta=0.020$ \\
\hline
\end{tabular}

Table 3: electronic spectra and their parameters

\begin{tabular}{|l|c|c|c|}
\hline Schiff base /Complexes & Expected $\mathbf{m} / \mathbf{z}$ & Found $\mathbf{~} / \mathbf{z}$ & Peak assigned \\
\hline $\mathrm{C}_{16} \mathrm{H}_{14} \mathrm{~N}_{2} \mathrm{OFe}$ & 320.251 & 322.2 & $\mathrm{M}+2$ \\
\hline$\left[\mathrm{Mn}\left(\mathrm{C}_{16} \mathrm{H}_{13} \mathrm{~N}_{2} \mathrm{OFe}\right)_{2} \cdot 2 \mathrm{H}_{2} \mathrm{O}\right]$ & 701.233 & 700.8 & $\mathrm{M}$ \\
\hline$\left[\mathrm{Co}\left(\mathrm{C}_{16} \mathrm{H}_{13} \mathrm{~N}_{2} \mathrm{OFe}\right)_{2} \cdot 2 \mathrm{H}_{2} \mathrm{O}\right]$ & 705.228 & 707.1 & $\mathrm{M}+2$ \\
\hline$\left[\mathrm{Ni}\left(\mathrm{C}_{16} \mathrm{H}_{13} \mathrm{~N}_{2} \mathrm{OFe}\right)_{2} \cdot 2 \mathrm{H}_{2} \mathrm{O}\right]$ & 704.988 & 704.2 & $\mathrm{M}$ \\
\hline$\left[\mathrm{Cu}\left(\mathrm{C}_{16} \mathrm{H}_{13} \mathrm{~N}_{2} \mathrm{OFe}\right)_{2} \cdot 2 \mathrm{H}_{2} \mathrm{O}\right]$ & 709.841 & 711.1 & $\mathrm{M}+2$ \\
\hline$\left[\mathrm{Zn}\left(\mathrm{C}_{16} \mathrm{H}_{13} \mathrm{~N}_{2} \mathrm{OFe}\right)_{2} \cdot 2 \mathrm{H}_{2} \mathrm{O}\right]$ & 711.704 & 712.7 & $\mathrm{M}+1$ \\
\hline$\left[\mathrm{Pd}\left(\mathrm{C}_{16} \mathrm{H}_{13} \mathrm{~N}_{2} \mathrm{OFe}\right)_{2} \cdot 2 \mathrm{H}_{2} \mathrm{O}\right]$ & 752.715 & 753.4 & $\mathrm{M}+1$ \\
\hline$\left[\mathrm{Pt}\left(\mathrm{C}_{16} \mathrm{H}_{13} \mathrm{~N}_{2} \mathrm{OFe}\right)_{2} \cdot 2 \mathrm{H}_{2} \mathrm{O}\right]$ & 841.373 & 842.1 & $\mathrm{M}+1$ \\
\hline
\end{tabular}

Table: 4. Mass of schiff base organometallic and complexes.

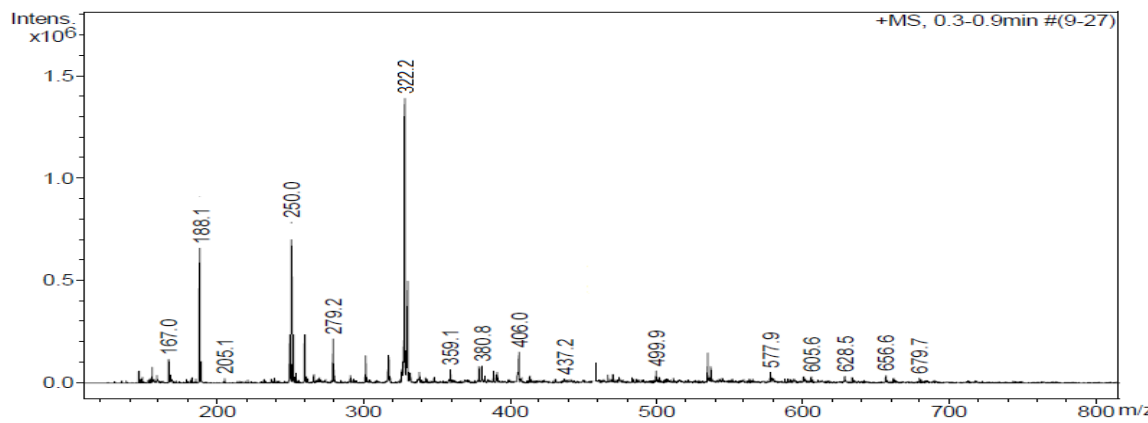

Fig 3: Mass Spectra of Schiff Base Organometallic Compound.

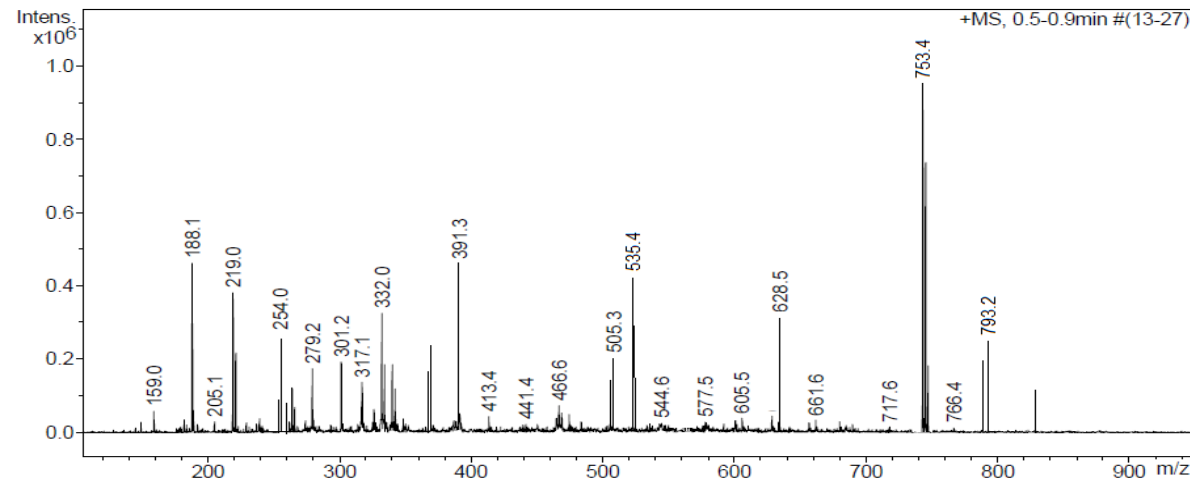

Fig 4: Mass Spectra Of $\left[\mathrm{Pd}\left(\mathrm{C}_{16} \mathrm{H}_{13} \mathrm{~N}_{2} \mathrm{OFe}\right)_{2 .} 2 \mathrm{H}_{2} \mathrm{O}\right]$ complex. 


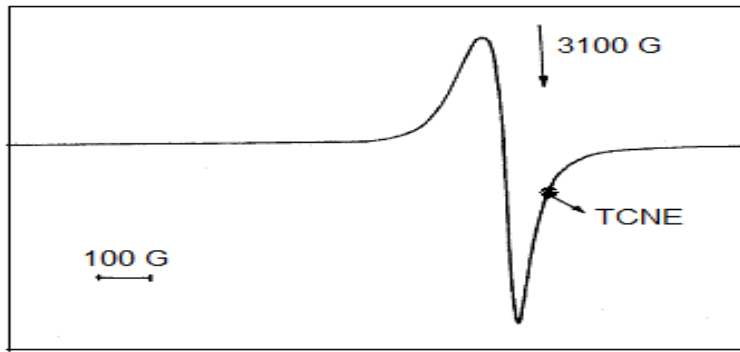

Fig 5: EPR of $\left[\mathrm{Cu}\left(\mathrm{C}_{16} \mathrm{H}_{13} \mathrm{~N}_{2} \mathrm{OFe}\right)_{2 .} 2 \mathrm{H}_{2} \mathrm{O}\right]$ complex.

\begin{tabular}{|l|c|c|c|}
\hline Schiff base /Complexes & Escherichia coli & P. aeruginosa & Staphylococcus Pyogones \\
\hline $\mathrm{C}_{16} \mathrm{H}_{14} \mathrm{~N}_{2} \mathrm{OFe}$ & + & + & ++++ \\
\hline$\left[\mathrm{Mn}\left(\mathrm{C}_{16} \mathrm{H}_{13} \mathrm{~N}_{2} \mathrm{OFe}\right)_{2} \cdot 2 \mathrm{H}_{2} \mathrm{O}\right]$ & ++ & + & ++ \\
\hline$\left[\mathrm{Co}\left(\mathrm{C}_{16} \mathrm{H}_{13} \mathrm{~N}_{2} \mathrm{OFe}\right)_{2} \cdot 2 \mathrm{H}_{2} \mathrm{O}\right]$ & ++ & ++ & + \\
\hline$\left[\mathrm{Ni}\left(\mathrm{C}_{16} \mathrm{H}_{13} \mathrm{~N}_{2} \mathrm{OFe}\right)_{2} \cdot 2 \mathrm{H}_{2} \mathrm{O}\right]$ & ++ & +++ & ++ \\
\hline$\left[\mathrm{Cu}\left(\mathrm{C}_{16} \mathrm{H}_{13} \mathrm{~N}_{2} \mathrm{OFe}\right)_{2} \cdot 2 \mathrm{H}_{2} \mathrm{O}\right]$ & +++ & +++ & ++ \\
\hline$\left[\mathrm{Zn}\left(\mathrm{C}_{16} \mathrm{H}_{13} \mathrm{~N}_{2} \mathrm{OFe}\right)_{2} \cdot 2 \mathrm{H}_{2} \mathrm{O}\right]$ & ++ & +++ & ++ \\
\hline$\left[\mathrm{Pd}\left(\mathrm{C}_{16} \mathrm{H}_{13} \mathrm{~N}_{2} \mathrm{OFe}\right)_{2} \cdot 2 \mathrm{H}_{2} \mathrm{O}\right]$ & +++ & +++ & ++ \\
\hline$\left[\mathrm{Pt}\left(\mathrm{C}_{16} \mathrm{H}_{13} \mathrm{~N}_{2} \mathrm{OFe}\right)_{2} \cdot 2 \mathrm{H}_{2} \mathrm{O}\right]$ & +++ & + & + \\
\hline
\end{tabular}

[Very Highly active = ++++ (inhibition zone $>20 \mathrm{~mm}$ ); Highly active $=+++($ inhibition zone $>15 \mathrm{~mm}$ ); slightly active $=++($ inhibition zone $>10 \mathrm{~mm})$; less active $=+($ inhibition zone $>5 \mathrm{~mm})]$

Table: 5. Microbial activity of schiff base organometallic compound and complexes.

\section{Conclusion:}

The organometallic compounds were synthesized and characterized various spectral techniques. The analytical data and spectral data indicate that, metal ligand stochiometric ratio is 1:2. Complexes are non electrolytes in nature. The spectral data indicates that, organometallic compounds are bidentate coordinating through nitrogen atom of the azomethane and oxygen atoms of hydroxyl group of the 4-[(E)-(Ferrocene-1Methylidene)Amino]Pyridin-2-ol . Complexes are assigned to be in octahedral geometry with coordination number is six. The pathogenic bacteria like Staphylococcus Pyogones shows more biological activity towards schiff base organometallic compound than its metal complexes. We are proposing the following probable structure of the complex $\left[\mathrm{M}\left(\mathrm{C}_{16} \mathrm{H}_{13} \mathrm{~N}_{2} \mathrm{OFe}\right)_{2} \cdot \mathbf{2} \mathrm{H}_{2} \mathrm{O}\right.$.

\section{Acknowledgements:}

Authors thanks to the Tata institute of fundamental research Mumbai, IPCA laboratories, Mumbai and C-MET for providing instrumentation facilities. Finally we thanks to friends, collogues and family members for their co-operation and help.

\section{References:}

[1] M.Ayad, S.Sallam and H.Mabrouk, Characterization and thermal behaviour of $\mathrm{Cu}$ (II) chelates of Schiff bases derived from aminopyridines. Thermo-Chimica Acta, 189, 1991, 65-73.

[2] H.Temel, U.Cakir and H.Ugras, Synthesis and characterization of $\mathrm{Zn}$ (II), $\mathrm{Cu}(\mathrm{II})$ and $\mathrm{Ni}(\mathrm{II})$ complexes with bidentate Schif $\mathrm{f}$ base ligands: Complexation studies and the determination of stability constant $(\mathrm{Ke})^{1}$, Russian Journal of Inorganic Chemistry, 46,2001, 1846-1850.

[3] S. Chang, L. Jones II, C. Wang, L. Henling and R. Grubbs, Synthesis and Characterization of New Ruthenium-Based Olefin Metathesis Catalysts Coordinated with Bidentate Schiff-Base Ligands Organometallics, 17 (16),1998, 3460-3465.

[4] M. Cifuentes, C. Powell , M. Humphrey, G. Heath, M.Samoc and B. Luther-Davies, Organometallic Complexes for Nonlinear Optics. 24. Reversible Electrochemical Switching of Nonlinear Absorption, J. Physical chemistry, 105 (42), 2001, 9625-9627.

[5] Z. Chohanand and M. Praveen, Synthesis, characterization, coordination and antibacterial properties of novel asymmetric 1,1'disubstituted ferrocene-derived Schiff-base ligands and their $\mathrm{Co}(\mathrm{II}), \mathrm{Cu}(\mathrm{II}) \mathrm{Ni}(\mathrm{II})$ and $\mathrm{Zn}$ (II) complexes, Applied Organometallic Chemistry, 15(7), 2001, 617-625.

[6] C. Jayabalakrishnan and K. Natarajan , Synthesis, Characterization, And Biological activities of Ruthenium(II) Carbonyl Complexes Containing Bifunctional Tridentate Schiff Bases, Synthesis and Reactivity in Inorganic and Metal-Organic Chemistry, 31(6),201,983-995.

[7] Z.Chohan, H. Shad, Metal-based new sulfonamides: Design, synthesis, antibacterial, antifungal, and cytotoxic properties, Journal of Enzyme Inhibition and Medicinal Chemistry, 27(3), 2012, 403-12. 
[8] S. Pandeya ,D. Sriram, G.Nath and E DeClercq, Synthesis, antibacterial, antifungal and anti-HIV activities of Schiff and Mannich bases derived from isatin derivatives and N-[4-(4'-chloro phenyl ) thiazol-2-yl] thiosemicarbazide. Europien J Pharm Science, 9(1), 1999,25-31.

[9] Z.Chohan , S. Sumrra, M. Youssoufi and K. Hadda , Metal based biologically active compounds: design, synthesis, and antibacterial/antifungal/cytotoxic properties of triazole-derived Schiff bases and their oxovanadium(IV) complexes, Europien $\mathrm{J}$ Medicinal Chemistry, 2010, 45(7), 2739-47.

[10] K Gupta and A. Sutar, Catalytic activities of Schiff base transition metal complexes, Coordination Chemistry Reviews, 252(1214), 2008, 1420-1450.

[11] R. Drozdzak, B.Allaert, N. Ledoux, I. Dragutan, V. Dragutan and F. Verpoort, Ruthenium complexes bearing bidentate Schiff base ligands as efficient catalysts for organic and polymer syntheses, Coordination Chemistry Reviews,249(24), 2005, 3055-3074.

[12] S.Pattanaik, S.Rout, J.Panda, P.Sahu and M. Banerjee, Synthesis, Characterisation and Biological Evaluation of Bidentate Ligands (Reduced Schiff's Base) With Metals Of Copper,Nickel and Zinc Complexes, Rasayan Journal Of Chemistry ,4(1),2011, 136-141.

[13] S. Biswas, A.Dutta, M.Debnath, M. Dolai, K. Das and M.Ali, A novel thermally stable hydroperoxo-copper(II) complex in a $\mathrm{Cu}\left(\mathrm{N}_{2} \mathrm{O}_{2}\right)$ chromophore of a potential $\mathrm{N}_{4} \mathrm{O}_{2}$ donor Schiff base ligand: synthesis, structure and catalytic studies, Dalton Trans., 42 , 2013 13210-13219.

[14] S. Borisov, R. Saf, R. Fischer and I. Klimant, Synthesis and Properties of New Phosphorescent Red Light-Excitable Platinum(II) and Palladium(II) Complexes with Schiff Bases for Oxygen Sensing and Triplet-Triplet Annihilation-Based Upconversion, Inorganic chemistry, 52 (3), 2013, 1206-1216.

[15] Z.Chohan and S. Kausar, Synthesis, structural and biological studies of nickel(II), copper(II) and zinc(II) chelates with tridentate Schiff bases having NNO and NNS donor systems, Chemical \& Pharmaceutical Bulletin, 41(5), 1993,951-953.

[16] A. Lenninger, D. Nelson and M.Cox, Principles of Biochemistry, Worth Publishers: New York, 1994.

[17] W.Geary, The use of conductivity measurements in organic solvents for the characterisation of coordination compounds. Coordination Chemistry Review, 7, 1971, 81-122.

[18] E. Tas, M. Aslanoglu, A. Kilic and Z. Kara,Synthesis, spectroscopic and electrochemical studies of copper(II) and cobalt(II) complexes of three unsymmetrical vic -dioximes ligands, Journal of Coordination Chemistry,59(8), 2006, 861-872.

[19] K Nakamato. Infrared and Raman Spectra of Inorganic and Coordination Compounds, $6^{\text {th }}$ Ed., John Wiley and Sons, Hoboken, New Jersey, 2009.

[20] Nakamoto, Infrared and Raman Spectra of Inorganic and Coordination Compounds, Part A and Part B, John Wiley \& Sons, New York, NY, USA, 1998.

[21] G.Mohamed, M. Omar and A. Ibrahim, Biological activity studies on metal complexes of novel tridentate Schiff base ligand, Spectroscopic and thermal characterization, Eur. J. Med. Chem., 44, 2009, and 4801.

[22] C.Spinu and A. Kriza, Co (II), Ni (II) and Cu (II) complexes of bidentate schiff bases, Acta Chim. Slov, 47, 2000,179.

[23] M Hossain, S.Chattopadhyay and S. Ghosh, Studies of nickel(II) complexes of 3-hydroxyiminobutanone thiosemicarbazone and 3hydroxyiminobutanone (4-phenyl thiosemicarbazone),Crystal structure of bis(3-hydroxyiminobutanone (4-phenyl thiosemicarbazone) nickel(II) nitrate, monohydrate, $\left[\mathrm{Ni}\left(\mathrm{C}_{11} \mathrm{H}_{14} \mathrm{~N}_{4} \mathrm{OS}\right)_{2}\right]\left(\mathrm{NO}_{3}\right)_{2} \cdot \mathrm{H}_{2} \mathrm{O}$, Polyhedron, 16,1997, 1793.

[24] A.Mishra and L.Pandey, Synthesis, structure and reactivity of oxovanadium(IV) Schiff base complexes, Indian Journal of Chemistry 44A,(9).2005, 1800-1805.

[25] A.Mishra, R. Mishra and S. Shrivastava, Structural and antimicrobial studies of coordination compounds of VO (II), Co (II), Ni (II) and $\mathrm{Cu}$ (II) with some Schiff bases involving 2-amino-4-chlorophenol, J. Serb. Chem. Soc. 74 (5), 2009, 523-535.

[26] A. Mishra, M. Khare and S. Gautam, Synthesis, physico-chemical characterization, and antibacterial studies of some bioactive Schiff bases and their metal chelates," Synthesis and Reactivity in Inorganic and Metal-Organic Chemistry, 32(8), 2002, 14851500

[27] C.Housecroft and A.Sharpe, Inorganic Chemistry, $2^{\text {nd }}$ Edition, England, Pearson Education Ltd, 2005,578

[28] M.Ajaily, F.Abdlseed and A. Ben-gweirif , Preparation, Characterization and Antibacterial Activity of Some Metal ion Complexes, E-Journal of Chemistry. 4(4). 2007, 461-466.

[29] K.George ,M.Lokhande and S.Bhusare, Synthesis and Characterization of Mn(II), Co(II), Ni(II), Cu(II) and Zn(II) complexes with 4- $\{(\mathrm{E})$-[(2-chlorophenyl) imino] methyl $\}$ benzene-1,2-diamine, Journal of Chemical, Biological and Physical Sciences. 2(1), 2011, $137-144$

[30] Z Steven, Chemical Principles $5^{\text {th }}$ Edn. Boston: Houghton Mifflin Company, 2005, 550-55.

[31] F.Cotton and G.Wilkinson, Advanced inorganic chemistry (New York: Wiley Interscience) 1962

[32] Advanced Inorganic Chemistry, Volume 2, $18^{\text {th }}$ edn, S. Chand publication, 2005, 247-253.

[33] V. Yang, B.Thomas and W.Zhen Ren, Solid Propellant Chemistry, Combustion, and Motor Interior , 185,2000,423-424.

[34] M. Brown, Introduction to Thermal Analysis: Techniques and Applications, academic publisher, 2001, 55-59.

[35] W.Fred, McLafferty, Interpretation of Mass Spectra, 4th edition, USA, 1993.

[36] M. Hamming, Interpretation of Mass Spectra of Organic Compounds, Academic press, USA, 2012

[37] A. Mishra, R. Mishra and S. Shrivastavaap, Structural and antimicrobial studies of coordination compounds Of VO (II), Co (II), Ni (II) and $\mathrm{Cu}$ (II) with some Schiff bases involving 2-amino-4-chlorophenol, J. Serb. Chemical Society, 74 (5), $2009,523-535$.

[38] B. Ding, L.Yi, W.Zheng Shen, P. Cheng, D.Zheng Liao, S.Ping Yan and Z.Hui Jiang, Synthesis, crystal structure and magnetic properties of N1,N2-bridged polynuclear Ni(II) complexesJournal of Molecular Structure,78491-3),2006, 138-143.

[39] B. Figgis, Introduction to Ligand Field, Wiley Eastern Ltd., New Delhi, 2005.

[40] R. Carlin and A. Van Dryneveledt, Magnetic Properties of Transition Metal Compounds, Springer Verlag, New York,1997.: ABP Lever, Inorganic ElectronicsSpectroscopy, Elsevier Amsterdam, 1968.

[41] J. Weil and J. Bolton, Electron Paramagnetic Resonance: Elementary Theory and Practical Applications, Wiley-Interscience, New York, 2001.]. 